\title{
Supply Chain Management Control of Fish Canning Industry in Morocco
}

\author{
Mohammed Hicham Hamri, P.E.S \\ Ilham Rharoubi, PhD
}

ERETTLOG Laboratory, National School of Commerce and Management of Agadir, ENCG-Agadir, University Ibn Zohr, Morocco

Doi: 10.19044/esj.2018.v14n10p332 URL:http://dx.doi.org/10.19044/esj.2018.v14n10p332

\begin{abstract}
Management control is increasingly adapted to the changes taking place at inter-firm level of business exchanges. By taking the form of an interorganizational control, the latter aims to reduce uncertainty, avoid opportunism and seek to make the most of an exchange relationship between two organizations. This article analyses some of the main studies dealing with inter-organizational control in the context of supply chain. We present literature review on this type of control, its typology and its approaches and theories.

Thanks to its marine biological heritage, Morocco is a world exporter of sea products. The fish preserve sector occupies an important place in the Moroccan economy with a large turnover. This paper presents an exploratory study of this sector where we try to explain the functioning within the canneries of the Souss Massa region in terms of logistic management, the management control function, the management of transport and costs and finally the performance management methods. Based on 12 interviews with managers of canneries in the region, the results of this exploratory study will form the basis on which we will base our main study.
\end{abstract}

Keywords: Inter-organizational management control, Inter-firm relationships, Supply chain, Canning fish industry.

\section{Introduction:}

Management control research has not yet taken into consideration new practices of inter-organizational cooperation. Several authors have emphasized the urgency of studying this field of research, which was the cause of publication of a number of works in this area. Previous research have focused on dyadic relationships that link two actors involved in an interorganizational relationship without trying to approach management control in 
a broader and multi-stakeholder inter-organizational context such as supply chains.

Management control as a classic theory focuses on the internal part of organizations. The management tools offered by management control system (cost management, planning, and performance control) are used vertically. However, many managers and researchers recognize the need to manage vertical as well as horizontal relationships, because organization's performance is influenced by what happens internally as well as externally. What poses a critical problem is to understand how to manage relationships with different actors and how to convince them knowing that they are not under the hierarchical obligation. We are talking about inter-organizational control. These external actors are supply chain partners.

The objective of this study is to describe logistic activity operation, the scope of the responsibilities delegated to the logistic manager, the cost management, as well as the performance management methods in fish canneries in Morocco. And in order to study inter-organizational control and its contribution to the management of the supply chain in the Moroccan context, we must first explore the sector studied or rather the state of its supply chain. And that is the most important point of this qualitative study.

\section{Research problem}

Over the years, many researchers in marketing and social sciences have shown the role of relationships in organizations (Morgan and Hunt 1994, Ricard and Perrien 1996, Ganesan 1994, Nogatchewsky 2004, Nogatchewsky and Donada, 2005).

Hopwood 1996 emphasized the necessity of investing this field of research. The author has strongly expressed the claim that control research has probably not yet taken the measure of new practices of inter-firm cooperation, according to the researcher planning, budgeting, and control processes move from one organization to other organizations in order to create greater awareness of the interdependence of actions and the role that joint action can play in the success of companies, then more explicit attention has been paid to the coordination of actions within organization networks which has resulted in creating concerns about quality, cost, and delivery time in supply chain management.

Several management control tools have been introduced to integrate the inter-organizational aspect to the function and to be able to answer the requirements posed by the management of inter-firm relations. Among these tools, we find the inter-firm prospective scorecard (Kaplan and Norton, 2006), strategic value chain cost analysis (Shank, 1989, Govindarajan and Shank, 1992) and open book accounting (Kajüter and Kulmala, 2005). 
Our article presents an exploratory study which is part of a research work, where we are interested in management control mechanisms in the interorganizational management of a supply chain, is there a control exerted on partners? Or supply chain actors of fish canning field? If so what are the types of control that exist? Is there a relationship between management control and logistics within the canned fish companies in the Souss Massa region? If yes, what is the type of this relationship? How do these two functions work together?

The research question we are trying to answer is therefore: To what extent does inter-organizational management control affect supply chain performance?

This study aims to explore the sector in question (canneries in Souss Massa region), its organization and its management, in order to answer the questions above in our future main research. This paper is composed of two parts, a theoretical part where we will discuss the subject of the interorganizational management control, and approaches on which it relies, furthermore the problems posed to the stakeholders. A second part presents a qualitative exploratory and descriptive study, carried out using the semidirective interview.

\section{Literature revue of inter-organizational management control Supply chain management}

The concept of supply chain is defined as "the network of organizations that are involved, through upstream and downstream linkages, in different processes and activities that produce value in the form of products and services in the hands of the ultimate consumer" (Christopher, 2005, p.13). According to Simchi-Levi et al. (2009) Supply Chain Management represents the set of methods used to effectively integrate suppliers, producers, warehouses and stores so that products are manufactured and distributed at the right quantities, in the right place and at the right time for the purpose of minimizing costs while ensuring that requirements are met.

Supply Chain Management is "a key strategic factor for increasing organizational effectiveness and for better realization of organizational goals such as enhanced competitiveness, better customer care and increased profitability" (Gunasekaran et al., 2001, p. 71). According to Stewart (1995), supply chain management aims to minimize non-value-added activities, minimize investment and operating costs, increase customer responsiveness and supply chain flexibility, and improve performance and cost competitiveness. 


\section{Supply chain performance}

According to Beamon (1999), supply chain's performance analysis only takes place after the implementation of the appropriate performance measures in order to achieve the objectives of supply chain. The author has shown that a supply chain performance measurement system must include three types of performance measurement; measuring costs, measuring customer service and measuring flexibility.

For Gunasekaran et al. in 2001, there are two reasons for having a performance measurement system and indicators in a supply chain; a lack of a balanced approach (between financial and non-financial measures) and a lack of clear distinction between measures at the strategic, tactical and operational levels.

Supply chain performance refers to supply chain activities to meet final- customer requirements, in terms of product availability, on-time delivery, and all the inventory and capacity required of a supply chain in order to provide the performance of the latter in a receptive manner (Hausman, 2004).

A supply chain performance measurement system aims to improve the supply chain efficiency and effectiveness, to capture the relevant aspects of the company's performance and to provide elements and information to assist decision-making for management (Holmberg 2000, Gunasekaran et al., 2004).

\section{Theoretical foundations of inter-organizational control}

According to Nogatchewsky and Donada (2005), the three most widely cited theories in inter-organizational relationships are the transactional approach, the relational approach and the power and dependency approach. Our revue of literature revealed a more specific theory to consider, which is Morgan and Hunt's theory of commitment and trust (1994) that was further developed by marketing researchers as well as relational approach.

\section{- Trust and commitment theory:}

Inspired by marketing theology, Morgan and Hunt founded the theory of commitment and trust in 1994 after noticing the collaborative aspect in business exchanges being neglected by researchers. Through this theory, these two authors show that there is a close link between trust and commitment.

The authors believe that relational marketing can only be successful if relational commitment and trust is established. They have started from an analysis of successful, productive and efficient business exchanges to those who are unproductive and ineffective, in order to conclude that commitment and trust are the keys to success, not power. When these two elements - not just one or the other - are present, they produce results that promote efficiency and productivity (Morgan and Hunt, 1994). 
According to the authors, these two factors are keys as they encourage marketers to; firstly, preserve relational investments by cooperating with trading partners, secondly to resist attractive alternatives in the short term in favor of long-term benefits and thirdly to consider that high-risk stocks are cautious because of the belief that their partners will not act in an opportunistic way.

The authors defined the relational commitment by the situation where the partners of an exchange think that the relationship is so important and that it must continue in spite of the maintained efforts. Commitment and trust are involved in creating cooperation within an exchange, and cooperative behavior is the key to successful relationship marketing.

\section{- Transactional approach:}

Oliver Williamson in 1975 developed transaction costs theory; he created the foundation of this theory and deduced different ways of governance that can exist for companies to control their transactions. Williamson has designated three control modes; control by the market (price system), hierarchy (within the organization) or hybrid forms (contracts). The author started from an initial analysis of the market and the company as much as two institutions of the economy in 1975, then bringing up the hybrid forms in 1985-1994 in order to be able to answer the critics on his first analysis.

The transaction cost theory states that exchanges between economic agents generate costs that are necessary for the development and maintenance of an exchange relationship and therefore diminish performance. These costs, called transaction costs, vary according to these transactions type, the level of assets and investments employed and the degree of opportunism and rationality of the players. For Williamson, lowering these costs as well as seeking protection from partners' opportunistic behavior of inter-firm relationships is among the most essential objectives of organizational management.

Williamson studied the three categories of contracts that Macneil (1973) proposed; conventional contracts, neoclassical contracts and relationship contracts. According to Williamson, Macneil thinks that any type of contract has the objective of facilitating exchanges. He also specified the right type of contract for each type of governance and transaction.

\section{- Relational and social approach:}

The relational approach has been developed by marketing researchers to meet the demands of the consumer and manage the relationship with customers, because for Crozier and Friedberg (1977) the consumer is a strategic player. This approach is subsequently adapted by researchers to all 
inter-organizational relationships even in a supply chain perspective (Donada and Nogatchewsky 2005, 2007 and Dekker et al., 2013).

For Larson (1992), relational-based exchanges are initially based on the success of past relationships and on reputations that will reduce uncertainty and set expectations and thereby improve cooperation. Thus a control system is needed for new relationships which are the result of the growing trust and the evolution of reciprocity norm; afterwards the exchange actors have become more operationally integrated and strategic. So instead of assessing costs and establishing legal contracts, effective control and coordination took place, so that opportunism was avoided and all for the purpose of maintaining trust and reputation. Larson (1992) believes that cooperation brings out explicit duties (communication and information sharing) and other implicit ones (transparency, honesty, fairness and reciprocity).

\section{- Power and dependence approach:}

Among the researchers who founded the power and dependency approach, Richard M. Emerson (1962) focused on the ambiguities between power, authority and legitimacy. He focused his attention on the properties of equilibrium in mutual power-dependency relationships. Nogatchewsky and Donada state that: "researchers in this approach understand exchange relationships according to the mutual dependence of their actors, which is inversely proportional to their power" (Nogatchewsky and Donada, 2005, p. 9).

The resource dependence theory of Pfeffer and Salancik (2003) represents the basis on which the power and dependence approach is based. According to this theory, inter-firm control is the strategic solution to situations of uncertainty and dependence.

The performance of inter-organizational relationships according to the power and dependency approach is based on efficiency, the objectives of exchange parties are to exercise their power, reduce uncertainty and avoid to be influenced by others. Moreover, the means of control in inter-firm relationship are often more or less coercive strategies of influence (Donada and Nogatchewsky, 2007).

Ouabouch and Akrich (2016) believe that the recording of control modes of an inter-firm exchange in a relational logic makes it possible to minimize the uncertainties induced by the business-partner relationship.

The foundation upon which inter-organizational control rests is built first by the precision of control objectives in terms of reducing uncertainty, convergence of goals and the exercise of power (Donada et al., 2012). 


\section{Supply chain management control}

According to Fiore and El Kartit (2016), management control action plan has been influenced by several changes in supply chain management. Among the changes cited by the authors; the downstream integration of the logistics chain, a strong informational dimension of logistics systems, the integration of supply systems and a consideration of strategic dimension of external relations upstream with suppliers but also downstream with customers.

The impact of supply chain management evolution on the general organizational field of application and on management control in particular is manifested in the transition from an inter-organizational management control to a supply chain management control (Fiore and El Kartit 2016). According to these two authors, a supply chain management control system is different in the way that it takes into consideration specific problems; it is most often accompanied by the mobilization of management tools and devices that favor inter-firm collaboration and information sharing.

A supply chain management control system is a set of institutional, functional and instrumental elements intended to support supply chain management in inter-organizational flows management and control of material, information and finances as well as different parts of the supply chain (Horch, 2009).

\section{Methodology}

For this work we have used the semi-directive interview given the exploratory and qualitative aspect of this study.

In the light of data saturation assumption (Glaser and Strauss, 1967, Bertaux, 1980, Savoie-Zajc, 2000) which confirms according to Pourtois and Desmet (2007) the credibility and transferability of research. Our sample was set in 12 interviews with managers from various canneries in the targeted region (5 director managers, 3 logistics managers, 2 accounting and finance directors, 1 export-import manager, 1 production manager).

These interviews deal with logistics and management control within the canning factories, as well as the used methods of improving performance and control procedures.

\section{Presentation of study results conducted on the fish canning field of Souss Massa region in Morocco}

The coast of Morocco spread over $3500 \mathrm{~km}$ and constitutes a rich diversity of fish in a good quality. In spite of that we observe from time to time a decline in the turnover of activity which is due to purchase irregularity of fresh fish. In order to be able to answer market's demand canneries are always in need of fresh fish as row material. This lack causes the decrease in 
production, which may involve conflicts with foreign partners about the failure to meet deadlines.

The fish canning sector is an evolving sector with strong export potential. According to Ministry of Agriculture, Fisheries, Rural Development, Water and Forests, the canning fish industry in 2012 generated an export turnover of 4.3 billion Dirhams, $39 \%$ of Moroccan canned fish is destined for European market and $43 \%$ for African market. This industry has a production capacity of more than 3000 tons per day, and offers thousands of jobs between permanent and seasonal.

\section{Study results and discussion}

\section{- Logistics}

Logistics within canneries has a large-scale place, encompassing any other activity that is part of the company's managing processes including production and products delivery. This function is also responsible for linking all external actors.

The logistics manager has a direct relationship with the general direction, that aims to learn about all field's news, in the national and international markets. Logistics manager is part of decision-making process; they are aware of predefined objectives and ensure that they are achieved.

For fish canneries, logistics management has changed in recent years trying to adapt to developments, this change is mainly due to the desire to expand business by following international standards in terms of safety and quality products as well as management. We also observe a partial change when acquiring or setting up new equipment as much as when establishing a new partnership.

\section{- The connection between management control and logistics}

The link between management control and logistics does not appear to be highly developed in Moroccan canneries. "Taking into consideration the necessity and the interest of this connection, the negligence of this coordination between these two functions is not satisfactory for us," says the manager of one of the canneries targeted. Managers are aware of this problem, but the constraints of time, budgets and lack of qualified personnel (logistic management controller, supply chain management controller) are the causes of this problem.

The only link between management control and logistics seems to be in terms of cost and inventory management. There is a kind of partial coordination between these two functions; "management control ensures to provide adaptable solutions for implementing and managing logistics, it contributes to logistic performance measurement by checking if the defined logistics objectives are reached or not" confirms one of our respondents. 
Budgets are drawn up annually and budgets management is carried out periodically, logistics costs distribution is sometimes difficult to perform except for outsourced services, which for logistics managers as well as management controllers an obstacle in accounting.

Logistics dashboard is a tool used by management control function, it brings together all the information that is useful and dispersed concerning logistics.

\section{- Performance practices}

Metrics are defined for the purpose of measuring performance; furthermore financial performance is the most evaluated periodically. Quality evaluation and improvement is an important part of canning organization, hence the use of quality control ratios. Companies always trying to ensure the good quality of materials received from suppliers. In addition to that, managers make sure that staff being recruited is qualified and well trained.

Logistic costs are calculated by accounting, they are distributed according to a distribution key or calculated in full as well as a service according to need, as mentioned by one of our respondents, "the calculation method used differs according to the request of the general management".

The choice of outsourcing partner is based on the three criteria; the price, the quality and the respect of the deadlines, we observe in this direction a focus on price and delay dimensions at the expense of quality. Regarding logistics performance, it is not always evaluated because of the high level of outsourcing of logistics services.

According to one of our interviewees, "The variety of canneries structures reduces the possibility of a complete comparison of performance between competitors, which is why we use benchmark by comparing with our previous results". Benchmarking practices are therefore reduced to historical comparisons, the elements compared are mainly costs, turnover and production volumes.

Supply chain management is not yet a concern in canneries management, a supply chain management system is only established in the large exporting firms located in the region or those with subsidiaries set up in the said region, this system is always used and manipulated at the level of the parent company, and which according to the manager of one of our canneries targeted: "consists in improving the flows over the extended chain that spreads from the first supplier to the final consumer while minimizing the costs and unnecessary activities".

\section{- Transport management}

Most companies use external contractors, land transport and shipping are the most used. The choice of carriers is based on prices, image and deadline 
compliance. Conditions such as: temperature monitoring, ventilation and impact resistance are also taken into consideration. Companies always aim to select carriers that are able to meet their requirements.

Canneries in Souss Massa region have a traceability system, especially exporting companies. In terms of product safety, this system verifies procedures application, compliance with the rules and expected quality. In terms of transport, traceability aims to keep track of products transport or storage, one of our interviewees confirmed that "a tracking system of maritime cities is essential to keep and guarantee the flow of goods from factory to customer, and vice versa, in the case of a withdrawal or recall of a specific product. Therefore traceability gives the intention to surveillance in order to know the position of the company in the chain as well as the origin and the destination of each product. This system is used to perform an audit in terms of application of procedures.

Failure to meet deadlines is in itself a cost generator, given the fact that this aspect is taken into account in the quality of seafood. As one of our respondents mentioned; "In term of choosing and evaluating suppliers, we give a lot of importance to the respect of delivery times of fresh fish. It represents one of the first criteria in choosing our fresh fish deliverers, especially for this raw material, hence the factor of quality".

\section{Conclusion and research perspectives}

Our study is purely exploratory. It represents the basis on which we will conduct our main study. Our work is a work in progress that will eventually be finalized by a quantitative study that will be part of a positivist paradigm using hypothetico-deductive method. In this paper, we try to cover the literature around inter-organizational control, the theoretical approaches on which it is found and the problems posed to actors by this control. We conclude by presenting features of management in fish canning industry of Souss Massa region in Morocco.

\section{References:}

1. Beamon, B. M. (1999). Measuring supply chain performance. International journal of operations \& production management, 19(3), 275-292.

2. Bertaux, D. (1980). L'approche biographique: sa validité méthodologique, ses potentialités. Cahiers internationaux de sociologie, 197-225.

3. Christopher, M. (2005). Supply chain management: créer des réseaux à forte valeur ajoutée. Village Mondial.

4. Crozier, M., \& Friedberg, E. (1977). L'acteur et le système. 
5. Dekker, H. C., Sakaguchi, J., \& Kawai, T. (2013). Beyond the contract: Managing risk in supply chain relations. Management Accounting Research, 24(2), 122-139.

6. Donada, C., \& Nogatchewsky, G. (2005). Vingt ans de recherches empiriques en marketing sur la performance des relations clientfournisseur. Recherche et Applications en Marketing (French Edition), 20(4), 71-96.

7. Donada, C., \& Nogatchewsky, G. (2007). La confiance dans les relations interentreprises. Revue française de gestion, (6), 111-124.

8. Donada, C., Nogatchewsky, G., \& Nogatchewsky, S. (2012). Gouvernance interorganisationnelle imbriquée et stratégie orientée client. Comptabilité-Contrôle-Audit, 18(2), 7-32.

9. Emerson, R. M. (1962). Power-dependence relations. American sociological review, 31-41.

10. Fiore, C., \& El Kartit, I. (2016, September). Quel système de contrôle de gestion pour piloter une Supply Chain?. In Rencontres Internationales de la Recherche en Logistique.

11. Ganesan, S. (1994). Determinants of long-term orientation in buyerseller relationships. the Journal of Marketing, 1-19.

12. Glaser, B. G., \& Strauss, A. L. (1967). The discovery of grounded theory: Strategies for qualitative research. New York: Aldlne.

13. Govindarajan, V., \& Shank, J. K. (1992). Strategic cost management: tailoring controls to strategies. Journal of Cost Management, 6(3), 1425.

14. Gunasekaran, A., Patel, C., \& McGaughey, R. E. (2004). A framework for supply chain performance measurement. International journal of production economics, 87(3), 333-347.

15. Gunasekaran, A., Patel, C., \& Tirtiroglu, E. (2001). Performance measures and metrics in a supply chain environment. International journal of operations \& production Management, 21(1/2), 71-87.

16. Hausman, W. (2004). Supply chain performance metrics. The practice of supply chain management: Where theory and application converge, 61-73.

17. Holmberg, S. (2000). A systems perspective on supply chain measurements. International Journal of Physical Distribution \& Logistics Management, 30(10), 847-868.

18. Hopwood, A. G. (1996). Looking across rather than up and down: on the need to explore the lateral processing of information. Accounting, Organizations and Society, 21(6), 589-590.

19. Horch, N. (2009). Management control of global supply chains. BoDBooks on Demand. 
20. Kajüter, P., \& Kulmala, H. I. (2005). Open-book accounting in networks: Potential achievements and reasons for failures. Management Accounting Research, 16(2), 179-204.

21. Kaplan, R. S., \& Norton, D. P. (2006). Alignment: Using the balanced scorecard to create corporate synergies. Harvard Business Press.

22. Larson, A. (1992). Network dyads in entrepreneurial settings: A study of the governance of exchange relationships. Administrative science quarterly, 76-104.

23. Le ministère de l'agriculture, de la pêche maritime, du développement rural et des eaux et forêts, département de la pêche maritime, activités de valorisation de l'industrie de la conserve de poisson 2012.

24. Macneil, I. R. (1973). The many futures of contracts. S. Cal. l. Rev., 47, 691.

25. Morgan, R. M., \& Hunt, S. D. (1994). The commitment-trust theory of relationship marketing. The journal of marketing, 20-38.

26. Nogatchewsky, G. (2004). Les configurations de contrôle dans les relations client-fournisseur (Doctoral dissertation, Université Paris Dauphine-Paris IX).

27. Ouabouch L. \& Akrich S. (2016). Gouvernance des relations interorganisationnelles en Supply Chain Management : dispositifs, management et performances. Revue Marocaine de Gestion et d'Economie, 3(7), 109-125.

28. Pfeffer, J., \& Salancik, G. R. (2003). The external control of organizations: A resource dependence perspective. Stanford University Press.

29. Pourtois, J. P., \& Desmet, H. (2007). Épistémologie et instrumentation en sciences humaines. Editions Mardaga.

30. Ricard, L., \& Perrien, J. (1996). Les facteurs explicatifs et normatifs d'une approche relationnelle: $\mathrm{La}$ perception des clients organisationnels. Association Française de Marketing, 12.

31. Savoie-Zajc, L. (2000). La recherche qualitative/interprétative en éducation, dans KARSENTI TS \& L. SAVOIE-ZAJC (dir.), Introduction à la recherche en éducation, Sherbrooke, Éditions du CRP.

32. Shank, J. K. (1989). Strategic cost management: new wine, or just new bottles. Journal of Management Accounting Research, 1(1), 47-65.

33. Simchi-Levi, D., Kaminsky, P., \& Simchi-Levi, E. (2009). Designing and Managing the Supply Chain 3rd.

34. Stewart, G. (1995). Supply chain performance benchmarking study reveals keys to supply chain excellence. Logistics Information Management, 8(2), 38-44.

35. Williamson, O. E. (1975). Markets and hierarchies. New York, 2630. 